\title{
ORIGINAL ARTICLE \\ Rapid, habitat-related evolution of land snail colour morphs on reclaimed land
}

\author{
M Schilthuizen \\ I made use of the known dates of reclamation (and of afforestations) in the IJsselmeerpolders in The Netherlands to assess \\ evolutionary adaptation in Cepaea nemoralis. At 12 localities (three in each polder), I sampled a total of 4390 adult individuals \\ in paired open and shaded habitats, on average $233 \mathrm{~m}$ apart, and scored these for genetic shell colour polymorphisms. The \\ results show (highly) significant differentiation at most localities, although the genes involved differed per locality. Overall, \\ though, populations in shaded habitats had evolved towards darker shells than those in adjacent open habitats, whereas a \\ 'Cain \& Sheppard' diagram (proportion yellow shells plotted against 'effectively unbanded' shells) failed to reveal a clear \\ pattern. This might suggest that thermal selection is more important than visual selection in generating this pattern. \\ Trait differentiation, regardless of whether they were plotted against polder age or habitat age, showed a linear increase of \\ differentiation with time, corresponding to a mean rate of trait evolution of 15-31 kilodarwin. In conclusion, $C$. nemoralis is \\ capable of rapid and considerable evolutionary differentiation over 1-25 snail generations, though equilibrium may be \\ reached only at longer time scales.
}

Heredity (2013) 110, 247-252; doi:10.1038/hdy.2012.74; published online 14 November 2012

Keywords: predation; crypsis; contemporary evolution; gastropoda; mollusca; adaptation

\section{INTRODUCTION}

In many animal and plant species, separate colour morphs exist within populations. Such colour polymorphisms have long been considered suitable trait systems to study contemporary evolution (Ford, 1945; Endler, 1986; Forsman et al., 2008), for several reasons. First, discrete colour morphs can often be scored easily and unambiguously in large numbers of individuals. Second, pigmentation type and pattern often have high heritability and a simple genetic basis (Reillo and Wise, 1988; Stewart and Lees, 1988; Wittkopp et al., 2009). Finally, colouration frequently responds strongly to natural and sexual selection (Gigord et al., 2001; Bell, 2008; Cook et al., 2012). Indeed, many studies demonstrating considerable contemporary evolution have made use of colour polymorphisms in organisms such as freshwater fish (Endler, 1980), intertidal and terrestrial snails (Hughes and Mather, 1986; Johnson, 2011), and owls (Karell et al., 2011).

One of the best known and most intensively studied model systems for selection on colour polymorphism is the land snail Cepaea. In Cepaea nemoralis and C. hortensis, two common European species, very conspicuous, and heritable (Murray, 1975), variation exists in shell colour and colour pattern. Shell ground colour ranges from bright yellow to deep brown and superimposed on this a variable pattern of dark brown spiral bands may exist (Lang, 1904; Goodhart, 1987). Numerous studies have shown that natural selection acts strongly on many of these colour morphs under different circumstances (though $C$. nemoralis often differs from $C$. hortensis in the exact response; Clarke, 1960). Evidence exists for selection for habitatdependent cryptic colouration by predation by the song thrush, Turdus philomelos (Cain and Sheppard, 1950, 1954; Lamotte, 1951; Carter, 1968). On the other hand, the effects of shell colour on the snails' thermoregulation (Heath, 1975) create a separate selection pressure, leading to summertime selection for shells with higher albedo in exposed habitats (Cain, 1968; Jones et al., 1977) and lower latitudes (Jones et al., 1977; Silvertown et al., 2011), and wintertime selection for light-coloured shells in topographies that are prone to extreme cold events (Cameron, 1969). In addition, some effects of shell colour on behaviour have also been reported: Wolda (1965) and Jones (1982) found that different colour morphs have different tendencies to climb trees, and to rest in exposed sites. Finally, phylogeographic patterns in allele predominance (so-called 'area effects') exist that may not be related to any direct environmental selection (Cain and Currey, 1963; Davison and Clarke, 2000). Because of this mixture of evolutionary forces and the spatial scales at which they operate, it has often been difficult to untangle the precise mechanism for observed colour differentiation (Jones et al., 1977; Cook, 1998).

Although direct and conclusive evidence for the type and strength of selection is available only in a few cases, many studies confirm that shaded and open habitats in the same area (where the larger-scale effects do not interfere) have significantly different morph frequencies. In general, shaded habitats tend to have lower frequencies of yellow and higher frequencies of effectively unbanded (Cain and Sheppard, 1950, 1954), although the latter effect does not appear everywhere (Lamotte, 1966; Cook, 2008; Silvertown et al., 2011; Cameron and Cook, 2012b). Also, populations in shaded habitats often are reported to have higher frequencies of band fusion (Clarke, 1960; Richards and Murray, 1975; Ożgo, 2011).

This habitat-related selection in Cepaea is often quoted as an example of contemporary, though relatively slow (requiring at least 
100 generations; Cook, 1998) evolution. However, only in a few studies are the ages of the populations and/or the habitats known with some certainty, allowing evolutionary rates to be estimated. For example, Richards and Murray (1975) made use of a C. nemoralis population introduced into North America, and demonstrated that, in this population fixed for yellow shell ground colour, shaded habitat populations had obtained significantly higher banding and higher band fusion frequencies over a period of at least 43 years. Similarly, Ożgo and Bogucki (2011) performed a transplant experiment in Poland, showing that, over 11 years, frequencies of yellow and yellow effectively unbanded in C. nemoralis diverged slightly but significantly between open and shaded habitats. Ożgo and Kinnison (2008) detected strong shell colour divergence in three open/sheltered habitat pairs in southeastern Poland that had presumably been established 18-28 years previously. Ożgo (2011), finally, surveyed 12 newlyestablished open/shaded habitat pairs in Germany and Poland (presumably 60-80 years old) and concluded that most of these showed significantly higher frequencies of yellow and lower frequencies of band fusion in the open habitats.

These studies suggest that, with a generation time of around 3 years (Jones et al., 1977; Cook, 1998), Cepaea populations can diverge under habitat-associated selection in time spans much less than 100 generations. However, it may be argued that larger series of timecontrolled (natural) experiments with known dates of population establishment are needed for a proper assessment of evolutionary rates in Cepaea. Here, I adopt the Dutch IJsselmeerpolders to provide such a system. These large areas of reclaimed land (polders) around the former Zuiderzee estuary were drained in the mid-20th century and subsequently colonised by flora and fauna, including C. nemoralis. As the C. nemoralis populations inhabiting paired open/ shaded habitats in these polders cannot be older than the polders themselves, and as the four major polders were drained with 11-15 intervening years, they allow evolutionary rates to be estimated with some accuracy.

\section{MATERIALS AND METHODS}

\section{Genetics and scoring system for the Cepaea shell colour} polymorphism

Murray (1975) summarises the genetics of the shell colour polymorphism in C. nemoralis. The locus $C$ controls shell ground colour, with alleles that determine colours ranging from pale yellow to deep brown (in increasing dominance). The shell may also carry one to five dark brown spiral bands, which are sometimes fused with one another. Banding is controlled by the $B$ locus (linked with $C$ ). The dominant allele (for unbanded) suppresses a recessive allele for banding. At the unlinked $T$ locus the dominant allele suppresses bands 1 and 2, leaving only the three lowest bands. The dominant allele at the $U$ locus removes bands 1,2, 4 and 5, making shells mid-banded. All banding categories with the top two bands absent are termed 'effectively unbanded'. The polygenic genetic control of band fusion, finally, is not yet resolved. Shell phenotypes are conventionally coded with a letter (Y, P or B) for the ground colour (yellow, pink and brown), followed by five digits (1-5), each replaced by a zero for a missing band. Band fusions (determined a quarter of a whorl away from the aperture) is coded with parentheses around the band digits that are joined. As an example, the following morphs are all effectively unbanded pink: P00000, P00300, P00345, P00(345), P003(45) and P00(34)5.

\section{Study areas and sampling}

The IJsselmeerpolders comprise four large areas in the north-central part of The Netherlands (see Figure 1): Wieringermeer (WI; $193 \mathrm{~km}^{2}$, drained in 1930), Noordoostpolder (NOP; $469 \mathrm{~km}^{2}, 1942$ ), Oostelijk Flevoland (OF; $\left.528 \mathrm{~km}^{2}, 1957\right)$ and Zuidelijk Flevoland (ZF; $\left.430 \mathrm{~km}^{2}, 1968\right)$. Today, the areas consist mostly of agricultural land, but also large industrial and residential areas exist, with scattered wetland and woodlands. To select habitat pairs, I used satellite images available in Google Earth and visited many suitable habitat pairs in the winter of 2010/2011, and, based on the availability of sufficient empty Cepaea shells, selected 12 pairs (three in each polder; see Figure 1 and Supplementary Table 1). Distances between the two habitats in a pair averaged $233 \mathrm{~m}$ (range: 35 to $650 \mathrm{~m}$ ) and were thus less than the minimum of $1 \mathrm{~km}$ recommended by Cameron and Cook (2012a). Using the historical aerial photographs available at http://historische-luchtfoto.flevoland.nl/, editions of topographic maps spanning much of the 20th century, and interviews with local foresters, I also estimated the year (in most cases \pm 3 years) in which each shaded habitat had appeared. In the remainder of this paper, I shall use the term 'locality' for each of the 12 places where habitat pairs were sampled, the term 'site' for a single habitat plot, and 'sample' for the snails collected in a site.

The sites were sampled between 11 May and 23 September, 2011. At each site, characteristics of the vegetation were recorded, and adult $C$. nemoralis snails were collected in a systematic fashion within a plot of $<5000 \mathrm{~m}^{2}$. I aimed to obtain at least 150 individuals from each of the 24 sites. Colour morphs were scored in the field, after which the snails were released back into the site. No attempt was made to quantify bird predation. Data were submitted to the online Cepaea polymorphism database Evolution Megalab (www. evolutionmegalab.org). Bird data show that all sites fell within areas with high densities of the song thrush (van Diermen, 2002). The soil at all sites consists of young marine clay with a high density of mollusk shells, except for Voorsterbos, which is on a fluvioglacial deposit (Wolters-Noordhoff, 2001).

\section{Analyses}

For each sample, I calculated the proportions (for all snails) of yellow, pink and brown, and unbanded, as well as effectively unbanded. I also calculated the proportions of all band combinations (of which 00300, 00345 and 12345 were the most abundant) among the banded category, and a measure for band fusion by taking the proportion of 5-banded snails with at least two bands fused. Differences in morph frequencies within each habitat pair were tested with $\chi^{2}$-tests. The euclidean distances generated from the morph frequency data were used to generate a phenogram for all samples using Ward-method in PAST 2.13 (Hammer et al., 2001). The pattern in frequencies yellow and effectively unbanded was inspected via a 'Cain and Sheppard diagram' (Cook, 2008).

In addition, for each snail, a 'darkness score' was determined. For this, I applied the data in Heath (1975) on the thermal properties of different colour morphs as follows. Using yellow unbanded as the base line, the expected temperature increases of other morphs were calculated by adding $0.3{ }^{\circ} \mathrm{C}$ for pink, $0.6{ }^{\circ} \mathrm{C}$ for brown, $0.07^{\circ} \mathrm{C}$ for each band and $0.03^{\circ} \mathrm{C}$ for each band fusion The resultant expected temperature increase was used as 'darkness score'. Differences in darkness between two sites of the same locality were tested for significance with Kruskall-Wallis one-way analysis of variance, and the overall significance was tested with Fisher's combined probability test.

Finally, for each habitat pair, I calculated a standardised measure for differentiation between the open and the shaded habitat for each of the major morph categories (that is, frequencies of P, B, YeU, banded, eU, 00300, 00345, 12345, fusion in 5-banded and fusion in all banded). I did this by taking the absolute value of $\log \left(\mathrm{P}_{\mathrm{O}} / \mathrm{P}_{\mathrm{S}}\right)$, in which $\mathrm{P}_{\mathrm{O}}$ is the frequency of the morph concerned in the open habitat, and $\mathrm{P}_{\mathrm{S}}$ in the shaded habitat. These differentiation measures were then correlated with polder age (see Figure 1) and estimated age of the shaded habitat (Table 1). Significance was assessed with an F-test. Under the assumption that the open habitat represented the original morph frequency and the shaded habitat represented the differentiated state, evolutionary rate was calculated (and expressed in kilodarwins; Haldane, $1949)$ as $\left(\ln \mathrm{P}_{\mathrm{S}}-\ln \mathrm{P}_{\mathrm{O}}\right) / t$ for all major morph categories (where $t$ is the time period in $10^{3}$ year).

\section{RESULTS}

In most sites, I obtained samples of around 150 individuals or more, except for Nagele Open and Shaded and Cirkelbos Open, where numbers were just under 100 . Total number of snails collected was 4390. The cluster analysis (Figure 2) shows some phylogeographic patterns: for five localities (Knarbos, Wilgenreservaat, Nagele, 


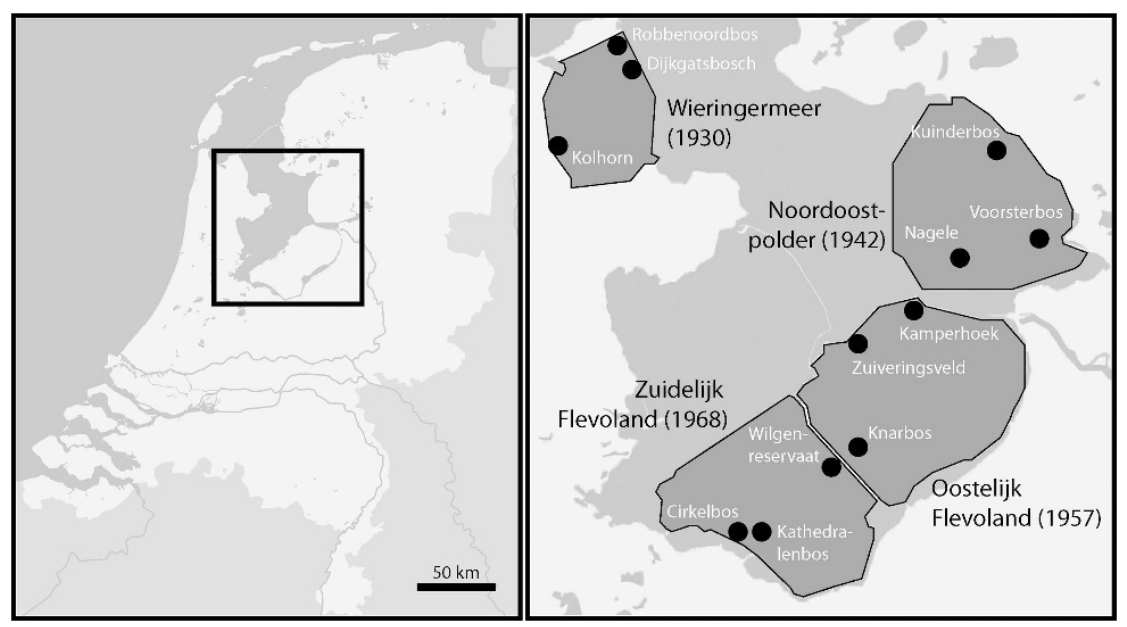

Figure 1 Map of The Netherlands (left) with the IJsselmeer (inset), the four land reclamation projects (and the years of draining) shown in dark grey. Black dots indicate the localities used in this study.

\section{Table 1 Morph frequencies and ages of sites}

\begin{tabular}{|c|c|c|c|c|c|c|c|c|c|c|}
\hline Site name & Open/closed & $\mathrm{N}$ & Yellow & Pink & Brown & Yellow (eU) & 00300 & 00345 & 12345 & fusion \\
\hline Kuinderbos & Shaded (46 year) & 197 & $101(0.51)$ & $36(0.18)$ & $60(0.30)$ & $67(0.34)$ & $3(0.05)$ & $21(0.34)$ & $33(0.53)$ & $18(0.55)$ \\
\hline Kuinderbos & Open & 182 & $134 \underset{* * *}{(0.74)}$ & $\begin{array}{c}36(0.20) \\
\text { NS }\end{array}$ & $12 \underset{* * *}{(0.07)}$ & $113_{* * *}^{(0.62)}$ & $21 \underset{* *}{(0.20)}$ & $53 \underset{*}{(0.50)}$ & $21 \underset{* * *}{(0.20)}$ & $1 \underset{* * *}{(0.05)}$ \\
\hline Nagele & Shaded (56 year) & 97 & $3(0.03)$ & $43(0.44)$ & $51(0.53)$ & $1(0.01)$ & $0(0.00)$ & $1(0.03)$ & $36(0.90)$ & $14(0.39)$ \\
\hline Nagele & Open & 91 & $\begin{array}{c}3(0.03) \\
\text { NS }\end{array}$ & $73 \underset{* * *}{(0.80)}$ & $15 \underset{* * *}{(0.16)}$ & $\begin{array}{l}0(0.00) \\
\text { NS }\end{array}$ & $\begin{array}{c}0(0.00) \\
\text { NS }\end{array}$ & $\begin{array}{c}0(0.00) \\
\text { NS }\end{array}$ & $\begin{array}{c}44(1.00) \\
\text { NS }\end{array}$ & $7 \underset{*}{(0.16)}$ \\
\hline Voorsterbos & Shaded (7 year) & 196 & $169(0.86)$ & $21(0.11)$ & $6(0.03)$ & $92(0.47)$ & $6(0.04)$ & $83(0.49)$ & $76(0.44)$ & $9(0.12)$ \\
\hline Voorsterbos & Open & 175 & $111_{* * *}^{(0.63)}$ & $55_{* * *}^{(0.31)}$ & $\begin{array}{c}9 \text { (0.05) } \\
\text { NS }\end{array}$ & $\begin{array}{c}87(0.50) \\
\text { NS }\end{array}$ & $45 \underset{* * *}{(0.37)}$ & $44 \underset{*}{(0.36)}$ & $25 \underset{* * *}{(0.21)}$ & $\begin{array}{c}3(0.12) \\
\mathrm{NS}\end{array}$ \\
\hline Knarbos & Shaded (36 year) & 179 & $102(0.57)$ & $30(0.17)$ & $47(0.26)$ & $17(0.09)$ & $17(0.16)$ & $2(0.02)$ & $89(0.82)$ & $43(0.48)$ \\
\hline Knarbos & Open & 219 & $84 \underset{* * *}{(0.38)}$ & $\begin{array}{c}48(0.22) \\
N S\end{array}$ & $87 \underset{* *}{(0.40)}$ & $3_{* * *}^{(0.01)}$ & $2 \underset{* * *}{(0.02)}$ & $\begin{array}{l}1(0.01) \\
\mathrm{NS}\end{array}$ & $92_{* *}^{(0.96)}$ & $\begin{array}{c}39(0.42) \\
\text { NS }\end{array}$ \\
\hline Zuiveringsveld & Shaded (46 year) & 153 & $52(0.34)$ & $72(0.47)$ & $29(0.19)$ & $46(0.30)$ & $21(0.31)$ & $24(0.35)$ & $17(0.25)$ & $4(0.24)$ \\
\hline Zuiveringsveld & Open & 228 & $\begin{array}{c}78(0.34) \\
\text { NS }\end{array}$ & $\begin{array}{c}95(0.42) \\
\text { NS }\end{array}$ & $\begin{array}{c}55(0.24) \\
\text { NS }\end{array}$ & $\begin{array}{c}69(0.30) \\
\text { NS }\end{array}$ & $\begin{array}{c}30(0.27) \\
N S\end{array}$ & $\begin{array}{c}55(0.50) \\
\text { NS }\end{array}$ & $\begin{array}{c}18(0.16) \\
\text { NS }\end{array}$ & $\begin{array}{c}3(0.17) \\
\text { NS }\end{array}$ \\
\hline Kamperhoek & Shaded (36 year) & 223 & $136(0.61)$ & $46(0.21)$ & $41(0.18)$ & $106(0.48)$ & $47(0.28)$ & $77(0.46)$ & $40(0.24)$ & $25(0.63)$ \\
\hline Kamperhoek & Open & 185 & $\begin{array}{c}118(0.64) \\
\text { NS }\end{array}$ & $14 \underset{* * *}{(0.08)}$ & $53 \underset{*}{(0.29)}$ & $\begin{array}{c}105 \text { (0.57) } \\
\text { NS }\end{array}$ & $\begin{array}{c}34(0.31) \\
\text { NS }\end{array}$ & $\begin{array}{c}63(0.57) \\
\text { NS }\end{array}$ & $13 \underset{*}{(0.12)}$ & $\underset{* *}{2(0.15)}$ \\
\hline Dijkgatsbosch & Shaded (57 year) & 151 & $98(0.65)$ & $31(0.21)$ & $22(0.15)$ & $71(0.47)$ & $5(0.06)$ & $43(0.48)$ & $35(0.39)$ & $13(0.37)$ \\
\hline Dijkgatsbosch & Open & 155 & $52 \underset{* * *}{(0.34)}$ & $85 \underset{* * *}{(0.55)}$ & $\begin{array}{c}18(0.12) \\
\text { NS }\end{array}$ & $28 \underset{* * *}{(0.18)}$ & $17 \underset{*}{(0.15)}$ & $\begin{array}{c}46(0.41) \\
N S\end{array}$ & $\begin{array}{c}48(0.43) \\
N S\end{array}$ & $3_{* * *}^{(0.06)}$ \\
\hline Kolhorn & Shaded (69 year) & 239 & $185(0.77)$ & $3(0.01)$ & $51(0.21)$ & $148(0.62)$ & $1(0.01)$ & $82(0.68)$ & $37(0.31)$ & $16(0.43)$ \\
\hline Kolhorn & Open & 168 & $165(0.98)$ & 1 (0.01) & $2(0.01)$ & $160(0.95)$ & $2(0.13)$ & $\begin{array}{c}7(0.47) \\
N S\end{array}$ & $\begin{array}{c}5(0.33) \\
\text { NS }\end{array}$ & $\begin{array}{c}0(0.00) \\
\text { NS }\end{array}$ \\
\hline Robbenoordbos & Shaded (77 year) & 161 & $91(0.57)$ & $3(0.02)$ & $67(0.42)$ & $61(0.38)$ & $8(0.13)$ & $23(0.36)$ & $33(0.52)$ & $16(0.48)$ \\
\hline Robbenoordbos & Open & 278 & $\begin{array}{c}153(0.55) \\
\text { NS }\end{array}$ & $51 \underset{* * *}{(0.18)}$ & $74_{* * *}^{(0.27)}$ & $\begin{array}{c}118(0.42) \\
\text { NS }\end{array}$ & $\begin{array}{c}19(0.13) \\
N S\end{array}$ & $79 \underset{*}{(0.53)}$ & $49 \underset{*}{(0.33)}$ & $7 \underset{* * *}{(0.14)}$ \\
\hline Cirkelbos & Shaded (2 year) & 158 & $127(0.80)$ & $31(0.20)$ & $0(0.00)$ & $87(0.55)$ & $39(0.30)$ & $49(0.37)$ & $42(0.32)$ & $18(0.43)$ \\
\hline Cirkelbos & Open & 96 & $\begin{array}{c}76(0.79) \\
\text { NS }\end{array}$ & $\begin{array}{c}20(0.21) \\
\text { NS }\end{array}$ & $\begin{array}{c}0(0.00) \\
\text { NS }\end{array}$ & $\begin{array}{c}59(0.61) \\
\text { NS }\end{array}$ & $\begin{array}{c}17(0.26) \\
N S\end{array}$ & $\begin{array}{c}28(0.42) \\
N S\end{array}$ & $\begin{array}{c}20(0.30) \\
\text { NS }\end{array}$ & $\begin{array}{c}9(0.45) \\
\text { NS }\end{array}$ \\
\hline Kathedralenbos & Shaded (22 year) & 148 & $64(0.43)$ & $75(0.51)$ & $9(0.06)$ & $35(0.24)$ & $16(0.13)$ & $36(0.30)$ & $66(0.55)$ & $40(0.61)$ \\
\hline Kathedralenbos & Open & 163 & $136 \underset{* * *}{(0.83)}$ & $4 \underset{* * *}{(0.02)}$ & $23 \underset{*}{(0.14)}$ & $93_{* * *}^{(0.57)}$ & $35 \underset{* *}{(0.30)}$ & $\begin{array}{c}34(0.29) \\
\mathrm{NS}\end{array}$ & $42_{* *}^{(0.36)}$ & $8 \underset{* * *}{(0.19)}$ \\
\hline Wilgenreservaat & Shaded (36 year) & 216 & $182(0.84)$ & $31(0.14)$ & $3(0.01)$ & $46(0.21)$ & $25(0.15)$ & $3(0.02)$ & $135(0.81)$ & $40(0.53)$ \\
\hline Wilgenreservaat & Open & 332 & $253(0.76)$ & $77 \underset{*}{(0.23)}$ & $\begin{array}{c}2(0.01) \\
\text { NS }\end{array}$ & $\begin{array}{c}65 \text { (0.20) } \\
\text { NS }\end{array}$ & $\begin{array}{c}41(0.18) \\
\text { NS }\end{array}$ & $\begin{array}{c}2(0.01) \\
\text { NS }\end{array}$ & $\begin{array}{c}184(0.80) \\
\text { NS }\end{array}$ & $8 \underset{* * *}{(0.19)}$ \\
\hline
\end{tabular}

Abbreviation : NS, not significant.
The estimated age (in years, \pm 3 year) at the time of sampling is given for the shaded habitat. Yellow (eU) comprises all yellow shells with bands 1 and 2 missing. Frequencies of banding categories are given as the proportion of all banded snails. For rarer banding categories, see Supplementary Table 1 . Band fusion is calculated as the number of 5 -banded snails with at least two bands fused. Statistical significances $\left(\chi^{2}\right.$-test): NS $P>0.05 ;{ }^{*} P<0.05 ;{ }^{* *} P<0.01 ;{ }^{* * *} P<0.001$.

Zuiveringsveld and Cirkelbos) do the open and shaded samples of a pair cluster together. Also, there is a slight indication of area effects at the scale of polders; except for Dijkgatsbosch Open, the WI samples all fall within one branch of the phenogram. Similarly, the frequency of B appears to be low in ZF compared with the other polders (Table 1).

The morph frequencies (Table 1) show that most habitat pairs differ significantly for three or more morphs, except for Cirkelbos and Zuiveringsveld. However, most morphs do not show a consistent habitat pattern. In shaded habitats, there seem to be tendencies for $\mathrm{Y}$ and 12345 to increase, and for $\mathrm{P}$ and 00300 to decrease. Other morphs show about as many increases as decreases, or show no differences. The only consistent response is in fusion: all seven significant changes in band fusion are towards more fusion in the shaded habitat. The lack of a consistent response in other shell morphs is also apparent in the Cain and Sheppard diagram (Figure 3). When shell colour is converted to a general darkness score, however, patterns become clearer (Figure 4). In nine cases 


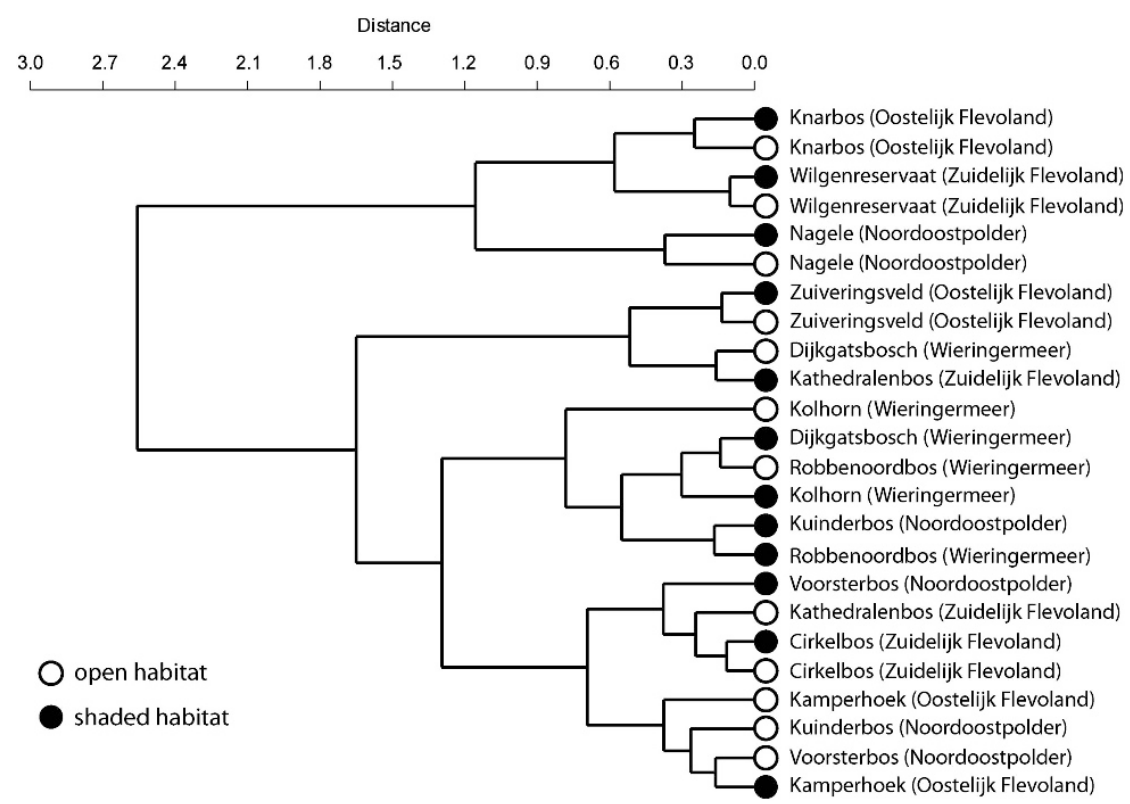

Figure 2 Phenogram of all samples, based on a (Ward-method) cluster analysis for euclidean distances among all morph frequencies.

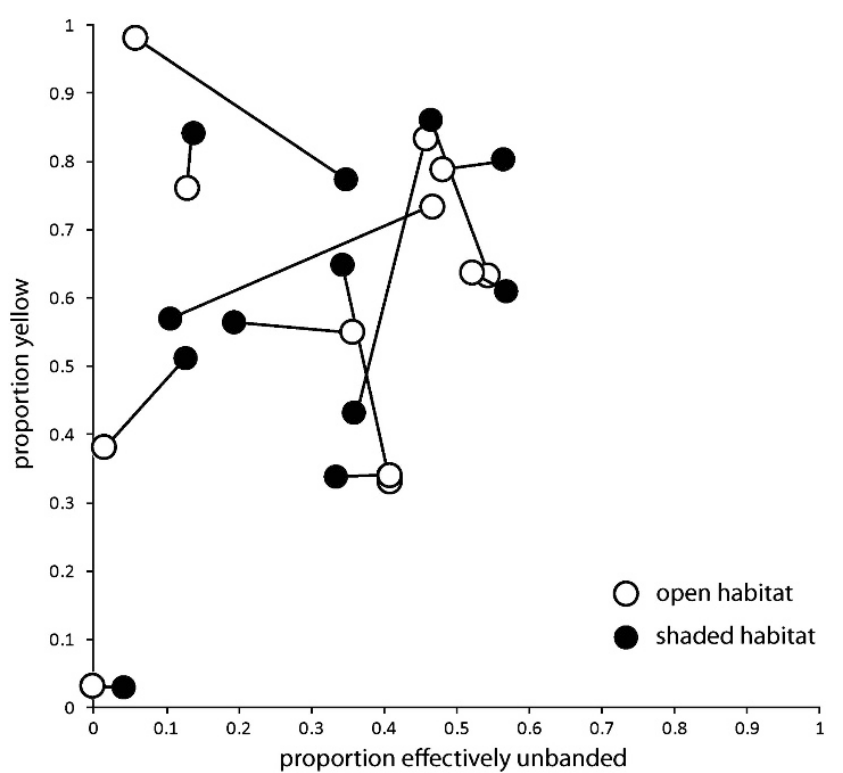

Figure 3 Cain and Sheppard diagram for all paired samples.

(seven of which are significant), shells in shaded habitats have a higher darkness score, and in only three (two significant) the pattern is reversed. The overall pattern of a change toward darker shells in shaded habitats is significant $(P<0.001$; Fisher's combined probability test; $\chi^{2}=115$; d.f. $=24$ ). Finally, open vs shaded habitat morph frequency difference shows positive and significant correlation with habitat and area age (Figure 5), leading to mean evolutionary rates of 14.7 (s.d. 20.7) and 31.4 (s.d. 45.2) kilodarwin (using polder age and habitat age, respectively).

\section{DISCUSSION}

Upon reclamation, the soil that developed in the IJsselmeerpolders provided a suitable habitat for terrestrial mollusks because of calciumrich marine clay (Jansen, 2010). It may thus be expected that open habitats suitable for Cepaea began to appear naturally very soon after reclamation was completed. Shaded habitats also appeared quickly, as forest was planted from saplings grown for this purpose at nurseries either within the polders themselves or on the 'old land' (Reinink, 1979). However, it appears that Cepaea was not introduced to the polders during this afforestation process, and in fact, only appeared many years after reclamation. In 1959, the species could not be found in grassland, woodland, nor the tree nurseries in OF, 2 years after reclamation (Jansen, 2010). Blaauw (1974), who surveyed land snails in ZF 5 years after reclamation, also records Cepaea as absent. Finally, Reinink (1979) failed to find Cepaea in ZF and OF in 1973/ 1974 (5-6 and 16-17 years after reclamation, respectively). $\mathrm{He}$ searched all tree nurseries and recently planted plots thoroughly and, finding no snails at all, concluded that the phytosanitary measures were very strict.

It thus appears that Cepaea has colonised the polders slowly and under its own power. It is therefore likely that it has entered planted woodlands after advancing through open habitat for several generations. More importantly, this means that any differences between populations in paired open and shaded habitats probably indeed evolved as these habitats appeared and that shaded habitats were not stocked with populations pre-adapted to woodland habitats. The pattern of colour morph variation in the polders suggests that these colonising populations retained sufficient genetic diversity to adapt to newly-arising environments, and also that some geographical structuring is present. In some cases, the populations from open habitat are, despite divergent evolution (see below), more similar in morph frequencies to the shaded habitat in the same locality than to other populations inhabiting open habitats.

The results show, for most localities, strong differentiation in several morph frequencies between open and shaded habitat (Table 1). When converted to a general darkness score, a significant tendency in the expected direction exists, namely towards darker shells in shaded habitats (seven significant cases), with a minority (two significant cases) showing the reversed response. Three cases (Nagele, Robbenoordbos and Zuiveringsveld) show no significant difference in darkness.

Absence of differentiation may be due to a rate of gene flow that is too great for differentiation to build up. In the case of Nagele, this is a 


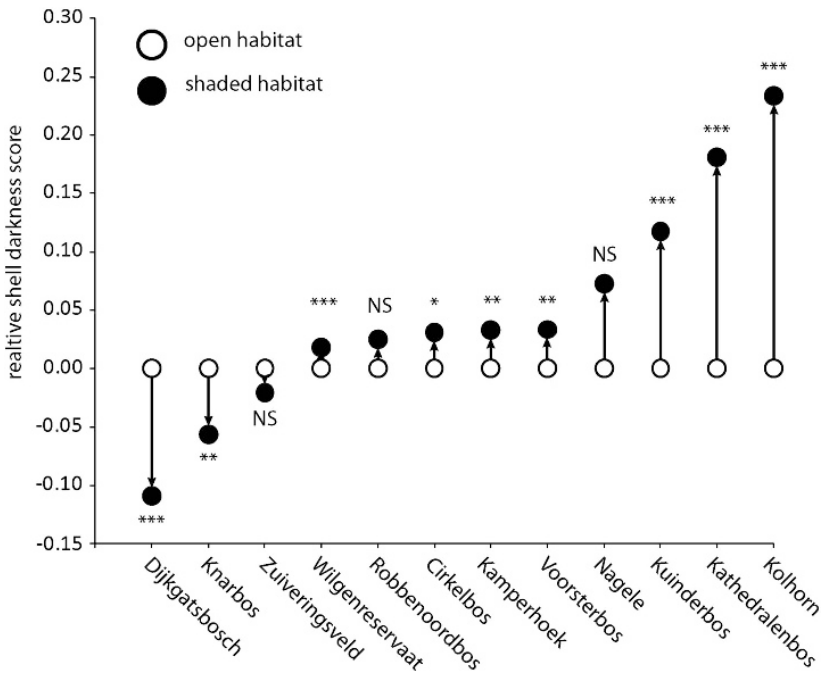

Figure 4 Diagram showing mean darkness scores for the shaded habitats compared with the corresponding open habitats (for convenience, darkness score set to zero for the open habitat). Statistical significances (Kruskall-Wallis one-way analysis of variance): NS $P>0.05$; ${ }^{*} P<0.05$; ${ }^{*} P<0.01 ;{ }^{* *} P<0.001$. The overall pattern of a change towards darker shells in shaded habitats is significant $(P<0.001$; Fisher's combined probability test).
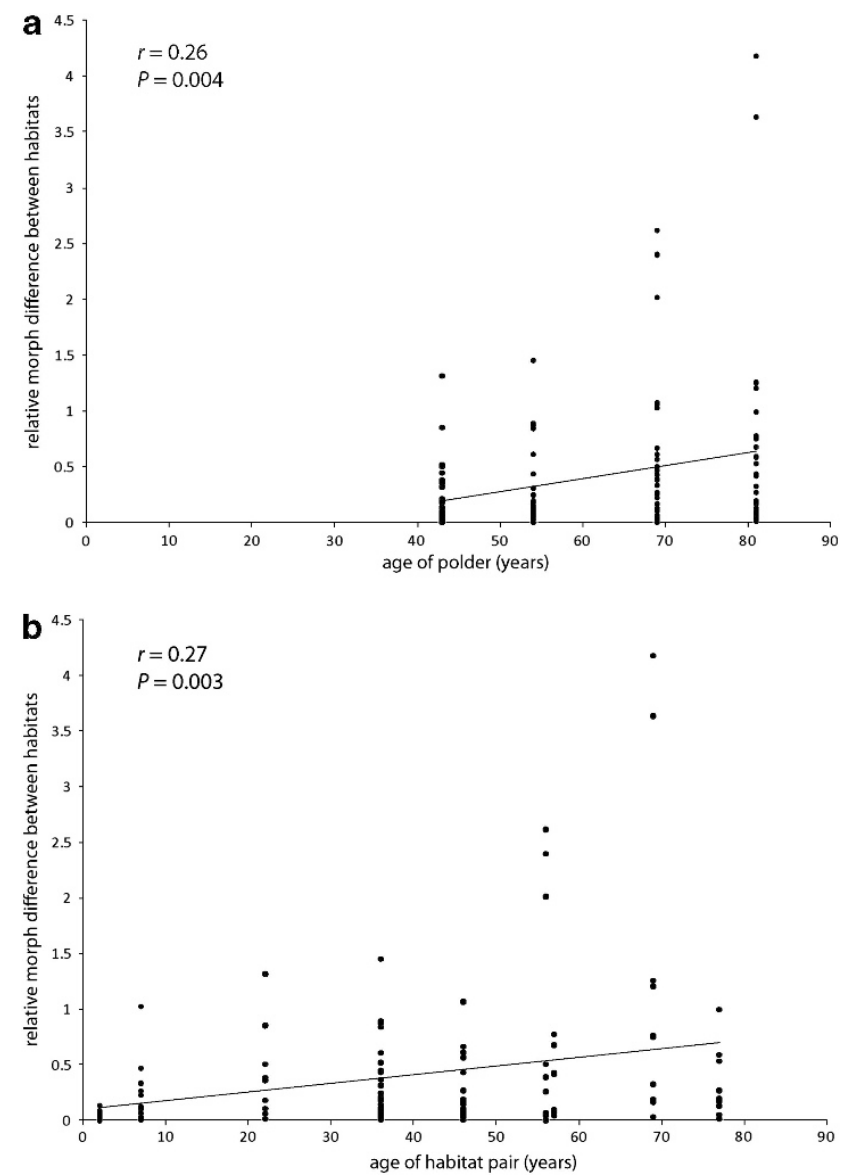

Figure 5 Relative frequency differences in all major morph categories for open vs shaded habitat for each locality, plotted against polder age (a) and estimated age of the shaded habitat (b). Significance of correlation coefficient $(r)$ was assessed with F-tests. plausible explanation, as the open habitat is a narrow strip of reedland immediately adjacent to the woodland (at a distance of the same magnitude as the per-generation dispersal in C. nemoralis; Jones et al., 1977). At Robbenoordbos and Zuiveringsveld, however, this cannot be the case, as the two habitats, which have existed for several decades, are separated by 650 and $180 \mathrm{~m}$, respectively, and, in both cases, by a road and two ditches. It is therefore not clear what may have prevented differentiation at these two localities.

The pattern for the remaining localities, of a majority of cases with darker shells in shaded habitat and a minority of cases with a reversed pattern, has been encountered before (Ożgo, 2005; Cook, 2008; Cameron and Cook, 2012a). It is generally assumed that the combined effects of visual selection and thermal selection tend to work in the same direction, that is, towards darker shells in the shaded habitat, but may sometimes work in opposite directions, depending on the alleles present in the population, the exact vegetation structure (which differed within the open and shaded habitat categories), and the season in which most selection takes place (Jones et al., 1977). As a consequence of the relative strengths of thermal and visual selection pressures, this may sometimes lead to lighter shells in the shaded habitat.

Nonetheless, the majority of the IJsselmeerpolder localities show darker shells in the shaded habitat. The shell morphs responsible, however, differ strongly per locality. For example, at Kathedralenbos, yellow is decreased dramatically in favour of pink. At Kolhorn, yellow is also decreased, but here in favour of brown. At Voorsterbos, yellow is actually increased, but this is more than compensated by a greater number of banded snails. The only morph change that seems to be consistent across all localities is towards more band fusion in the shaded habitat. A similarly predictable response of band fusion was also found by, for example, Ożgo (2011). In fact, surprisingly, the categories most often reported to show consistent responses to habitat, that is, yellow and effectively unbanded, show no indication of a consistent response (Cain and Sheppard diagram; Figure 3). Cameron and Cook (2012b) similarly found that the habitat separation in a Cain and Sheppard diagram is only clear in Southern England and disappears on large parts of the European mainland. As changes in these colour morphs are most often thought to be associated with visual selection, it may be argued that the evolutionary changes that we do see in the present study are caused primarily by thermal selection, rather than visual selection. In this respect, it must also be pointed out that the inheritance and heritability of band fusion (the trait that contributes most consistently to shell darkness in this study) is far from clear (Lang, 1904; Murray, 1975), and further experiments to elucidate this are needed.

The chief aim of this paper was to examine the rate of evolutionary change, by making use of the known ages of the polders and the habitats in them. Interestingly, significant positive correlations exist between morph frequency differentiation and age, both for the age of the entire polder and for the respective habitats. Ages are given in years, but as generation time in C. nemoralis is $c .3$ years (Jones et al., 1977; Cook, 1998), the range equates with a time scale of 1-25 snail generations. Over this time scale, evolutionary change in shell colour traits appears to accumulate with a mean rate of $15-31 \mathrm{kDar}$, and Figure $5 \mathrm{~b}$ suggests that this process has not yet stabilised. It should be emphasised that these are minimum rates: the (limited) data on colonisation history suggest that the polders were not colonised immediately, and, hence, snail populations may, in some cases, have been established considerably later than the polders and/or the habitats, or there may have been a history of extinction and recolonisation. It should also be emphasised that the evolutionary 
change is not just the result of habitat-related selection, but probably include other kinds of genetic differentiation (for example, founder events and genetic drift) as well. Future work on comparisons of genetic differentiation across the same habitats in different polders and vice versa might enable separation of these multiple effects.

The rates of evolutionary change found here may be considered high (Kinnison and Hendry, 2001; Bell, 2008), and they clearly show that, indeed, as reported by Ożgo (2011), Ożgo and Kinnison (2008) and Ożgo and Bogucki (2011), Cepaea is capable of very rapid adaptive divergence in shell colouration in response to different habitat conditions. At the same time, the fact that evolutionary divergence seems to be greatest in those habitat pairs that have existed around 80 years ( 27 generations), it is not impossible that divergence will reach equilibrium only on a time scale close to 100 generations, as suggested by Cook (1998).

\section{DATA ARCHIVING}

Data have been deposited at Dryad: doi:10.5061/dryad.6d86v.

\section{CONFLICT OF INTEREST}

The author declares no conflict of interest.

\section{ACKNOWLEDGEMENTS}

I thank Małgorzata Ożgo for sharing her vast knowledge of Cepaea biology with me and for providing the pre-defined spreadsheets that form the basis for Supplementary Table 1. Jan Akkerman and Ruben Kluit (Natuurmonumenten), Ed Colijn (European Invertebrate Survey-The Netherlands), Roelof Duijff (Flevolandschap), and Harco Bergman (Staatsbosbeheer) provided crucial information on the history of the polders and their habitats. Three anonymous referees provided comments that considerably improved the paper.

Bell G (2008). Selection; the Mechanism of Evolution, 2nd edn. Oxford University Press: Oxford.

Blaauw J (1974). De Malacofauna van het IJsselmeer, de IJsselmeerpolders en de Randmeren. Unpublished MSc thesis University of Amsterdam.

Cain AJ (1968). Studies on Cepaea. V. Sand dune populations of Cepaea nemoralis (L.) Phil Trans R Soc Lond B 253: 499-517.

Cain AJ, Currey JD (1963). Differences in interactions between selective forces acting in the wild on certain pleiotropic genes in Cepaea. Nature 197: 411-412.

Cain AJ, Sheppard PM (1950). Selection in the polymorphic land snail Cepaea nemoralis Heredity 4: 275-294.

Cain AJ, Sheppard PM (1954). Natural selection in Cepaea. Genetics 39: 89-116.

Cameron RAD (1969). The distribution and variation of three species of land snail near Rickmansworth, Hertfordshire. J Linn Soc Zool 48: 83-111.

Cameron RAD, Cook LM (2012a). Correlated phenotypic responses to habitat difference in Cepaea nemoralis (L.). Folia Malacol. in press.

Cameron RAD, Cook LM (2012b). Habitat and the shell polymorphism of Cepaea nemoralis (L.): interrogating the Evolution Megalab database. J Moll Stud 78: 179-184.

Carter MA (1968). Thrush predation of an experimental population of the snail Cepaea nemoralis (L.). Proc Linn Soc Lond 179: 241-249.

Clarke BC (1960). Divergent effects of natural selection on two closely-related polymorphic snails. Heredity 14: 423-443.

Cook LM (1998). A two-stage model for Cepaea polymorphism. Proc $R$ Soc Lond B 353 1577-1593.

Cook LM (2008). Variation with habitat in Cepaea nemoralis: the Cain \& Sheppard diagram. J Moll Stud 74: 239-243.

Cook LM, Grant BS, Saccheri IJ, Mallet J (2012). Selective bird predation on the peppered moth the last experiment of Michael Majerus. Biol Lett 8: 609-612.

Davison A, Clarke B (2000). History or current selection? A molecular analysis of "area effects" in the land snail Cepaea nemoralis. Proc R Soc Lond B 267: 1399-1405.

Endler JA (1980). Natural selection on color patterns in Poecilia reticulata. Evolution 34: 76-91.

Endler JA (1986). Natural Selection in the Wild. Princeton University Press: Princeton.

Ford EB (1945). Polymorphism. Biol Rev 20: 73-88.

Forsman A, Ahnesjö J, Caesar S, Karlsson M (2008). A model of ecological and evolutionary consequences of color polymorphism. Ecology 89: 34-40.

Gigord LDB, Macnair MR, Smithson A (2001). Negative frequency-dependent selection maintains a dramatic flower color polymorphism in the rewardless orchid Dactylorhiza sambucina (L.) Soò. Proc Natl Acad Sci USA 98: 6253-6255.

Goodhart GB (1987). Why are some snails visibly polymorphic and others not? Biol J Linn Soc 31: 35-58

Haldane JBS (1949). Suggestions as to quantitative measurement of rates of evolution. Evolution 3: 51-56.

Hammer $\varnothing$, Harper DAT, Ryan PD (2001). PAST: paleontological statistiscs software package for eductaion and data analysis. Palaeontol Electr 4: 1-9.

Heath DJ (1975). Colour, sunlight and internal temperatures in the land-snail Cepaea nemoralis (L.). Oecologia 19: 29-38.

Hughes JM, Mather PB (1986). Evidence for predation as a factor in determining shel color frequencies in a mangrove snail Littorina sp. (Prosobranchia: Littorinidae). Evolution 40: 68-77.

Jansen B (2010). Kruipende Huisjes; Verspreiding en Bijzonderheden van in de Zuidelijke IJsselmeerpolders Aangetroffen Land- en Zoetwatermollusken (Slakken en Mossels), met Beschrijvingen van Natuurterreinen. Stichting Anemoon/Natura Parva: Bennebroek.

Johnson MS (2011). Thirty-four years of climatic selection in the land snail Theba pisana. Heredity 106: 741-748.

Jones JS (1982). Genetic differences in individual behaviour associated with shell polymorphism in the snail Cepaea nemoralis. Nature 298: 750-751.

Jones JS, Heith BH, Ralwings P (1977). Polymorphism in Cepaea: a problem with too many solutions? Annu Rev Ecol Syst 8: 109-143.

Karell P, Ahola K, Karstinen T, Valkama J, Brommer JE (2011). Climate change drives microevolution in a wild bird. Nature Comm 2: 208.

Kinnison MT, Hendry AP (2001). The pace of modern life II. From rates of contemporary microevolution to patterns and process. Genetica 112/113: 145-164.

Lamotte M (1951). Recherches sur la structure génétique des populations naturelles de Cepaea nemoralis (L.). Bull Biol Fr Supp/ 35: 1-239.

Lamotte M (1966). Les facteurs de la diversité du polymorphisme dans les populations naturelles de Cepaea nemoralis (L.). Lav Soc Malac Ital 3: 33-73.

Lang A (1904). Ueber Vorversuche zu Untersuchungen über die Varietätsbildung von Helix hortensis Müller und Helix nemoralis L. Denk Med-Naturw Ges Jena 11: 437-506.

Murray J (1975). The genetics of the Mollusca. In: King RC (ed.) Handbook of Genetics, Vol. 3. Plenum: New York.

Ożgo M (2005). Cepaea nemoralis (L.) in Southeastern Poland: associations of morph frequencies with habitat. J Moll Stud 71: 93-103.

Ożgo M (2011). Rapid evolution in unstable habitats: a success story of the polymorphic land snail Cepaea nemoralis (Gastropoda: Pulmonata). Biol J Linn Soc 102: 251-262.

Ożgo M, Bogucki Z (2011). Colonization, stability, and adaptation in a transplant experiment of the polymorphic land snail Cepaea nemoralis (Gastropoda: Pulmonata) at the edge of its geographic range. Biol J Linn Soc 104: 462-470.

Ożgo M, Kinnison MT (2008). Contingency and determinism during convergent contemporary evolution in the polymorphic land snail, Cepaea nemoralis. Evol Ecol Res 10 721-733.

Reillo PR, Wise DH (1988). An experimental evaluation of selection on color morphs of the polymorphic spider Enoplognatha ovata (Araneae: Theridiidae). Evolution 42. $1172-1189$

Reinink K (1979). Observations on the distribution of land snails in the woods of the IJsselmeer polders. Basteria 43: 33-45.

Richards AV, Murray JJ (1975). The relation of phenotype to habitat in an introduced colony of Cepaea nemoralis. Heredity 34: 128-131.

Silvertown J, Cook LM, Cameron RAD, Dodd M, McConway K, Worthington J et al. (2011) Citizen science reveals unexpected continental-scale evolutionary change in a mode organism. PLOS ONE 6: e18927.

Stewart AJA, Lees DR (1988). Genetic control of colour pattern polymorphism in British populations of the spittlebug Philaenus spumarius (L.) (Homoptera: Aphrophoridae). Biol J Linn Soc 34: 57-79.

van Diermen J (2002). Zanglijster Turdus philomenos. In: SOVON Vogelonderzoek Nederland (eds). Atlas van de Nederlandse Broedvogels 1998-2000. Nationaal Natuurhistorisch Museum Naturalis, KNNV Uitgeverij \& European Invertebrate Survey-Nederland: Leiden, pp 362-363.

Wittkopp PJ, Stewart EE, Arnold LL, Neidert AH, Haerum BK, Thompson EM et al. (2009). Intraspecific polymorphism to interspecific divergence: genetics of pigmentation in Drosophila. Science 326: 540-544.

Wolda $\mathrm{H}$ (1965). Some preliminary observations on the distribution of the various morphs within natural populations of the polymorphic landsnail Cepaea nemoralis (L.) Arch Neerl Zool 16: 280-292.

Wolters-Noordhoff (2001). De Grote Bosatlas voor VMBO/HAVONWO. Wolters-Noordhoff Atlasproducties: Groningen.
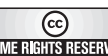

nported License. To view a copy of this license, visit http://creativecommons.org/licenses/by-nc-nd/3.0/

Supplementary Information accompanies the paper on Heredity website (http://www.nature.com/hdy) 